\title{
Behavior of some Bread Wheat Genotypes under Different Planting Dates and Nitrogen Fertilizer Levels in Sohag Governorate
}

\author{
Yasser A. M. Hefny and Naheif E. Mohammed
}

Received on: $11 / 4 / 2018$

\author{
Agronomy Dept., Fac. Agric., Sohag Univ.
}

\section{Abstract}

Accepted for publication on: 6/5/2018

Two field experiments were conducted in two successive seasons of 2015/2016 and 2016/2017 at the Research Farm Al-Kawthar, Faculty of Agriculture, Sohag University, to determine the effect of two planting dates (15 November and10 December) and three nitrogen fertilizer levels (50, 75 and $100 \mathrm{~kg}$ $\mathrm{N} /$ fed.) on yield and its components of four bread wheat genotypes (Sids 12, Giza 168, NGB 6404 and NGB 10893). A randomized complete block design (RCBD) in split- split plot with four replications was used. Data indicated that the planting dates were significantly effects on all studied traits except spike length and straw yield in both seasons, as well as nitrogen fertilizer levels and genotypes had significantly effect on the all studied traits; plant height $(\mathrm{cm})$, spike length $(\mathrm{cm})$, 1000-grain weight (g), grain yield (ard./fed.), biological yield (ton/fed.), straw yield (ton/fed.) and harvest index $(\%)$ in the both seasons. Increasing $\mathrm{N}$ up to 100 $\mathrm{kg} /$ fed increased yield and its attributes of wheat in both growing seasons except plant height $(\mathrm{cm})$, spike length $(\mathrm{cm})$ and harvest index $(\%)$. Sids 12 and NGB 10893 genotypes produced the highest values of grain yield compared to other genotypes in both seasons. Moreover, NGB 10893 accession produced the maximum values of spike length $(\mathrm{cm})$ and1000-grain weight $(\mathrm{g})$ in both seasons, while NGB 6404 accession produced the tallest plants. Late planting (10 December) increased significantly plant height $(\mathrm{cm})$, spike length $(\mathrm{cm}), 1000$-grain weight, grain yield (ard./fed.), biological and straw yields (ton/fed.).In general the highest grain yields (21.59 and 21.04 ard./fed.) were obtained by Sids 12 genotype when planted in 10 December and application of $100 \mathrm{~kg} \mathrm{~N} / \mathrm{fed}$., and NGB 10893 genotype when planted in 10 December and fertilized with $75 \mathrm{~kg}$ $\mathrm{N} /$ fed. interaction treatments, respectively.

Keywords: Wheat genotypes, plantingdates, nitrogen fertilizer levels and grain yield.

\section{Introduction}

Wheat is the most important strategic commodity for the populations all over the world and comes at the first order in Egypt, not only for human food but also for animal feeding. Wheat is the main winter cereal crop in Egypt and is widely distributed all over the country. The cultivated area (3.47 million feddans) in $2014 / 2015$ season with an average grain yield of 18.46 (ard./fed). Although, there was a good progress towards increasing the total wheat yield in Egypt in last year's still there is a big gap between the consumption and local production (32\%). The local production is about 9.61 million tons.

Nitrogen fertilizer plays a direct effect on growth behavior and yield quality, since nitrogen is the element which stimulates above-ground growth and produces the rich, green color characteristic of healthy plant and increases the protein percentage. 
Ali, Amal et al (2016) reported that increasing $\mathrm{N}$ fertilization level from 95.2 to $190.4 \mathrm{~kg} \mathrm{~N} /$ ha significantly increased all phonological traits, grain yield and its components and grain protein content of some durum and bread wheat varieties.

Sowing date is an important factor that affects phenophases and grain yield and its components of wheat (Kiss et al., 2013). Longer vegetative growth period due to sowing at optimal date, resulted in higher radiation use efficiency and better dry matter mobilization and higher values for grain yield and its components (Sun et al., 2013; Eslami et al., 2014 and Anwar et al., 2015). Sowing date may, alsohave an impact on quality characters of wheat especially protein content. Gheith et al.(2013) studied the response of some bread wheat genotypes during 2011/2013 years and he concluded that all studied genotypes have been superior in early sowing dates (25 Nov.), while late sowing dates (10 and 25 Dec.) and low nitrogen application had significantly declined yielding capacity of wheat genotypes. Rising temperatures in recent years due to global climate change affect the growth and productivity of grain crops, especially wheat crop. This study aimed to determine the optimal planting dates and nitrogen fertilizer levels of some bread wheat genotypes.

\section{Materials and Methods}

To examine the response of wheat grain yield and its attributes to planting dates and nitrogen fertilization on four bread wheat genotypes Sids 12 and Giza 168 (Egyptian varieties) in addition NGB 6404 and NGB 10893 accessions (their seeds were imported in 2010 from Nordic Genetic Resource Center (Nord Gen) then, after adapted under Sohag conditions) were sown in two planting dates $\left(15^{\text {th }}\right.$ November and $10^{\text {th }}$ December). Three nitrogen levels 50, 75 and $100 \mathrm{~kg} \mathrm{~N} /$ fed., were used during 2015/2016 and 2016/2017 winter seasons.

A randomized complete block design (RCBD) in split-split-plot with four replications was used. The bread wheat genotypes and the treatments were distributed randomly as following: 1) Planting dates were placed in the main plots. 2) The genotypes were laid out in the sub-plots. 3) The nitrogen fertilizer levels were fixed in the smallest plots, where the plots area was $10.5 \mathrm{~m}^{2}$ (3.5 m length $\mathrm{x} 3.0$ $\mathrm{m}$ width), includingof15 rows with 20 $\mathrm{cm}$ apart between them.

Seeding rate was used as recommended (60 kg/fed.). Ammonium nitrate $(33.5 \% \mathrm{~N})$ was used as source of nitrogen fertilizer, and the treatments applied in three splits each, 20, 40 and $40 \%$ at sowing, first irrigation and 30 days later, respectively. The experiment soil was sandy-clay texture, with $\mathrm{pH} 7.6$, electrical conductivity $0.60 \mathrm{dS} \mathrm{m}^{-1}$, total nitrogen 1.68 $\mathrm{g} / \mathrm{kg}$ and organic matter $2.61 \%$.All other agriculture practices were carried out as recommended.

\section{Data recorded:}

Plant height and yield components (spike length, 1000-grain weight and harvest index) were recorded as recommended procedure. Biological and grain yields were recorded by weighing all above ground dry matter of each plot, then grain separating and weighing in kilograms 
and converted into ton and ard./fed., respectively.

\section{Statistical analysis:}

The data was statistically analyzed each season separately by Proc GLM procedure (SAS Version 9.1, SAS Institute 2003) described by COStat (2004) as well as the least significant differences (LSD) test among the means of factor levels and their interactions at probability level at 5\% was used according to Gomez and Gomez 1984.

\section{Results and discussion}

The grain yield and its component of wheat genotypes are dramatically affected not only by alteration of sowing dates according to the region temperature, but also by mineral nitrogen fertilizer levels depending on the broad genetic makeup of the wheat genotype. Kiss et al., 2013 and Sun et al., 2013 confirmed that wheat genotypes responded significantly by sowing dates. Ali et al. (2011), Eslami et al. (2014) and Anwar et al. (2015) studied the effect of nitrogen fertilizers on growth, yield and components of wheat genotypes and summarized that physiological, growth traits and grain yield enhanced by $\mathrm{N}$ fertilizer.

In the present investigation, the most studied traits were responded significantly to genotypes, planting dates, nitrogen fertilizer levels, and their first and second order interactions effect.

\section{1- Planting Dates:}

Planting date had the significantly affected by sowing dates for all studied traits were found in Table (1),except spike length and straw yield had insignificantly effected by this trial in both seasons. These re- sults may be due to the genetic effects on spike length and straw yields more than environmental effects.

Performance the highest most studied traits of wheat plants were resulted from the late sowing $\left(10^{\text {th }}\right.$ Dec.), since the tallest plants (92.19 and $97.67 \mathrm{~cm}$ ), the maximum1000kernel weight (46.99 and $48.18 \mathrm{~g}$ ), grain yields (17.03 and 17.95 ard./fed.), biological yields (5.36 and 5.76 ton/fed.) and harvest index (48.10 and $47.06 \%$ ) in the first and second seasons, respectively. These results due to rising air temperature during November more than December, caused decline the growth characters such as number of tillers and elongation more than the agronomic traits. The results of Malik et al. (2009) sustained our dissections, where he observed decline the number of tillers at $15^{\text {th }}$ Nov. (247.3 till$\mathrm{ers} / \mathrm{m}^{2}$ ) compared to sowing at $30^{\text {th }}$ Nov. (285.8 tillers $/ \mathrm{m}^{2}$ ). Abdel nour, Nadia and Fateh (2011) in their study at El-Sharkia Governorate stated that the date at $25^{\text {th }}$ of November produced the highest number of spikes $/ \mathrm{m}^{2}$, number of kernels /spike, 1000-kernel weight, biological yield and grain yield. Moreover, Said et al. (2012) found that increasing the number of grains (50.1) spike $^{-1}, 1000$ grain weight (32.1gm), biological yield $\left(6824 \mathrm{~kg} \mathrm{ha}^{-1}\right)$ and grain yield $\left(2336 \mathrm{~kg} \mathrm{ha}^{-1}\right)$ were obtained from late sowing $\left(15^{\text {th }}\right.$ December $)$.

\section{2-Genotypes:}

Data in Table (1) showed that the imported genotypes (G2 and G3) differed significantly and were taller than the Egyptian cultivars (G1 and G4) in both seasons, and this may be due to the morphological and geneti- 
cally differences between the studied genotypes. The genotype G3 was superior for other genotypes in spike length $(12.77$ and $14.14 \mathrm{~cm})$ and $1000-$ grain weight (52.17and $53.36 \mathrm{~g}$ ) in the first and second seasons, respectively, since, this genotypes characterized by longer spike and wider dimensions of grains. The highest grain yields were obtained from Genotypes G1 (18.38 and 19.17 ard./fed.) followed by G3 (17.81 and 18.74 ard./fed.), without significant differences between them in the both seasons, while the G2 was the lowest one (13.10 and 14.04 ard./fed.). The genotype G2 differed significantly for the others with the lowest values for biological and straw yields in both seasons. Also the minimum grain yield was observed in the genotype G2, exhibited the highest harvest index values in both seasons, this due to the increasing of its straw yield (1.97 and 2.21 ton/fed.) further than grain increased in the $1^{\text {st }}$ and $2^{\text {nd }}$ seasons, respectively. These results are in agreements with those obtained by Tahir et al. (2009), Gul et al. (2012), Lak et al. (2013) and Upadhyay et al. (2015).

\section{3-Nitrogen fertilizer levels:}

The presented data in Table (1) regarded that, the first level of nitrogen fertilizer $(50 \mathrm{~kg} \mathrm{~N} / \mathrm{fed}$.) differed significantly than the other highest two $\mathrm{N}$ levels, and exhibited the lowest values of all traits, except the harvest index values (49.24 and 47.89 $\%)$ were the highest values were produced by the lowest $\mathrm{N}$ level in both seasons, this due to decreasing the grain weight more than straw yield reduced, meanwhile without significant differences were found between
$\mathrm{N}$ fertilizer level (75 and $100 \mathrm{~kg}$ $\mathrm{N} /$ fed.) for all studied traits in $1^{\text {st }}$ and $2^{\text {nd }}$ seasons, that is means any further in increasing $\mathrm{N}$ fertilizer than 75 $\mathrm{kg} /$ fed., without any economic gains under these conditions. These results indicated that increasing the $\mathrm{N}$ levels from 50 to $75 \mathrm{~kg} \mathrm{~N} / \mathrm{fed}$., improved the associated physiological process and interpretation in the final grain yield and its components. These findings supported with those obtained by Sebastiano et al. (2005), Ahmed et al. (2011), Ali et al. (2011), Enayat et al. (2013), Youssef et al. (2013) and Shajaripour and Mojaddam (2014). Faizy et al.(2017) found that, increasing nitrogen fertilizer levels up to 80 $\mathrm{kg} \quad \mathrm{N} /$ fed significantly increased wheat grain yield $\left(\mathrm{ardab} \mathrm{fed}^{-1}\right)$, straw yield (ton $\mathrm{fed}^{-1}$ ) and 1000 grain weight $(\mathrm{g})$.

\section{4-Planting Dates $x$ genotypes inter- action (DxG):}

Data in Table 2 and Fig. 1 showed that the most studied traits were responded significantly affected by $\mathrm{DxG}$ interaction in the both seasons. The imported genotypes (G2 and G3) were affected positively in plant height with late sowing, since the tallest plants (103.99 and 109.77 $\mathrm{cm})$ followed by (100.06 and 105.56 $\mathrm{cm})$ were detected with NGB 6404 followed by NGB 10893 genotypes at the late sowing in the $1^{\text {st }}$ and $2^{\text {nd }}$ seasons, respectively. On the other hand, shortest plants $(81.69$ and $87.51 \mathrm{~cm})$ were detected by D2xG4 and D2xG1 interaction treatments in the $1^{\text {st }}$ and $2^{\text {nd }}$ seasons, respectively. Also, the longest spikes $(13.36$ and $14.77 \mathrm{~cm})$ was with the $\mathrm{G} 3$ of the late sowing in the $1^{\text {st }}$ and $2^{\text {nd }}$ seasons, respectively. This results due to the originated of 
the $\mathrm{G} 2$ and $\mathrm{G} 3$ in the colder weather than the Egyptian genotypes. The genotypes were interacted by sowing dates for 1000 -grain weight and the highest values $(51.66$ and $52.68 \mathrm{~g})$ and $(52.68$ and $53.73 \mathrm{~g})$ followed by $(51.66$ and $52.98 \mathrm{~cm})$ were obtained from G3 in the late and early sowing dates in first and second seasons, respectively. The interactions between DxG had significant effect on grain yield, where the highest values (19.12 and $20.05 \mathrm{ard}$./fed.) followed by (18.36 and 19.28 ard./fed.) then (17.64 and 18.29 ard./fed.) were obtained by D2xG1, D2xG3 and D1xG1 interaction treatments in the first and second seasons, respectively (Fig.1 and 2). The biological and straw yield unaffected significantly by the interaction of $\mathrm{DxG}$, in contrast the harvest index affected significantly by interaction of DxG, whereas the highest values $(50.13$ and $48.60 \%)$ followed by ( 49.74 and $48.82 \%$ ) were found by NGB 6404 genotype (G2), when was sowing in late and early dates in the first and second seasons, respectively The obtained results indicated that the highest harvest index resulted from increasing the grain yield further than the biological yield. Similar results were obtained by Sadek (2000), Ejaz et al.(2007), Rahman et al. (2009) and Munsif et al.(2015).

\section{5- Planting Dates $x$ Nitrogen fertil- izer levels interaction (DxN):}

The presented data in Table (2) showed that insignificant effects of DxN interaction on the plant height and spike length and its may be due to that these traits are genetic parameters. The 1000-grain weight increased significantly from 42.83 to $44.68 \mathrm{~g}$ and from 43.55 to $45.66 \mathrm{~g}$ at late and early sowing dates under $\mathrm{N}$ fertilizer $(50 \mathrm{~kg} \mathrm{~N} / \mathrm{fed}$.), while the increase 1000 -grain weight did not differ significantly by sowing dates under 75 and $100 \mathrm{~kg} \mathrm{~N} / \mathrm{fed}$., in both seasons, these results may be due to the maximum $\mathrm{N}$ use efficiency done by proper growth temperature in the late sowing. The response grain yield for $\mathrm{N} 2$ and N3 levels were not differ significantly by sowing dates, whereas the increasing rates of grain yield were higher in the late sowing than the early sowing. This result is meaning that the plants under low $\mathrm{N}$ fertilizer level were subjected to mineral stress and maturated early before hot weather occurred. On the other hand the interaction of DxN was insignificantly on biological, yield, straw yield and harvest index. These results might be due to the better plant establishment and growth in 10 December date which permitted the plants to fully benefit from higher application of nitrogen. Ali, Amal et al. (2016) stated that the sipkes $/ \mathrm{m}^{2}$, number of grains/spike were the highest at 190.4 $\mathrm{kg} \mathrm{N} / \mathrm{ha}$, in earlier (November $1^{\text {st }}$ ) and later (December $1^{\text {st }}$ ) sowing dates, respectively. These results are in harmony with those obtained by El- Gizawy (2009) and Dagash et al. (2014).

\section{6- Genotypesx Nitrogen fertilizer levels interaction $(\mathrm{GxN})$ :}

The data in Table (2) and Figs. ( 3 and 4) explained the behavior of the wheat genotypes under different $\mathrm{N}$ fertilizer rates. The significant effect of the GxD interaction was found for all studied traits, except spike length which did not affected significantly by this trial in both seasons. 
The genotypes G2 and G3 (imported genotypes) responded significantly in plant length $(\mathrm{cm}), 1000-$ grain weight, grain yield, biological and straw yield to nitrogen fertilization, when $\mathrm{N}$ rates increased from 50 $\mathrm{kg}$ until $75 \mathrm{~kg}$ N.fed., only, meanwhile the Egyptian genotypes (G1 and $\mathrm{G} 4$ ) responded significantly in the same previous traits till $100 \mathrm{~kg}$ $\mathrm{N} /$ fed. This means that the foreigner genotypes were higher in their nitrogen use efficiency, as well as these genotypes did not require further $\mathrm{N}$ fertilization. Alves et al. (2015) showed that the variation of yield and its attributes in response to increasing $\mathrm{N}$ fertilization levels in wheat varieties, to the genetic constitution ability of the genotypes to benefit from the amount of $\mathrm{N}$ applied in relation to environmental conditions. These results are in agreement with thosementioned by Allam (2003), El-Borhamy and Gadallah (2009) and Abd ElKreem, Thanaa and Ahmed (2013).

7- Planting Dates $x$ genotypes $x$ Nitrogen fertilizer levels interaction (DxGxN):

The significant affected of the third order interaction on plant height, 1000-grain weight, grain yield and harvest index (Table 3). The tallest plants $(106$ and $113 \mathrm{~cm})$ were observed in the genotype $\mathrm{G} 2$ at $75 \mathrm{~kg}$ $\mathrm{N} /$ fed in the late sowing (D2xG2xN2) interaction treatment in the first and second season respectively, while the shortest plants $(79.13 \mathrm{~cm})$ followed by $(81.33 \mathrm{~cm})$ were found in the genotype followed byG1 at the lowest $\mathrm{N}$ fertilizer level at lately and early sowing date i.e. (D2xG4xN1) and D1xG1xN1) interaction treatments in the first season, as well as the genotype G4 $(81.50 \mathrm{~cm})$ in the second $\mathrm{N}$ levels at late sowing date (D2xG4xN2) interaction treatments had the shortest plant. The genotype G3 had the heaviest in 1000-grain values (54.47 and 55.87\%) followed by $(53.80$ and $54.40 \mathrm{~g})$ and $(53.35$ and $54.73 \mathrm{~g})$ followed by (52.80 and $53.73 \mathrm{~g}$ ) at $\mathrm{N} 3$ and $\mathrm{N} 2$ at the late early sowing dates in the $2^{\text {nd }}$ season, respectively. The highest grain yield values (21.59 and 21.04 ard./fed.) were obtained from the genotype G1 at late sowing date, when fertilizer by $100 \mathrm{~kg} \mathrm{~N} / \mathrm{fed}(\mathrm{D} 2 \mathrm{xG} 1 \mathrm{xN3})$ and from the genotype G3 at the late sowing, when the $75 \mathrm{~kg} \mathrm{~N}$ level applied $(\mathrm{D} 1 \mathrm{xG} 3 \times \mathrm{N} 2)$ in the $2^{\text {nd }}$ season. The highest harvest index values (54.73 and 52.95) followed by 52.91, then (52.21 and $51.12 \%)$ were recorded from (D2xG3xN1) i.e. $\mathrm{G} 3$ at $50 \mathrm{~kg} \mathrm{~N}$ $/$ fed at $1^{\text {st }}$ and $2^{\text {nd }}$ season, followed by $\left(\mathrm{D} 2 \mathrm{xG}^{\mathrm{x} N} \mathrm{~N}\right)$ i.e. $\mathrm{G} 2$ at $\mathrm{N} 3$ level in the $1^{\text {st }}$ season at the late sowing date then $(\mathrm{D} 1 \mathrm{xG} 2 \mathrm{xN} 3)$ interaction treatment) i.e. G2 at $100 \mathrm{~kg} \mathrm{~N} / \mathrm{fed}$ at early sowing dates in the $1^{\text {st }}$ and $2^{\text {nd }}$ seasons respectively. The same conclusion was reported by Protic et al., (2007) and Abdelnour, Nadya and Fateh (2011). 


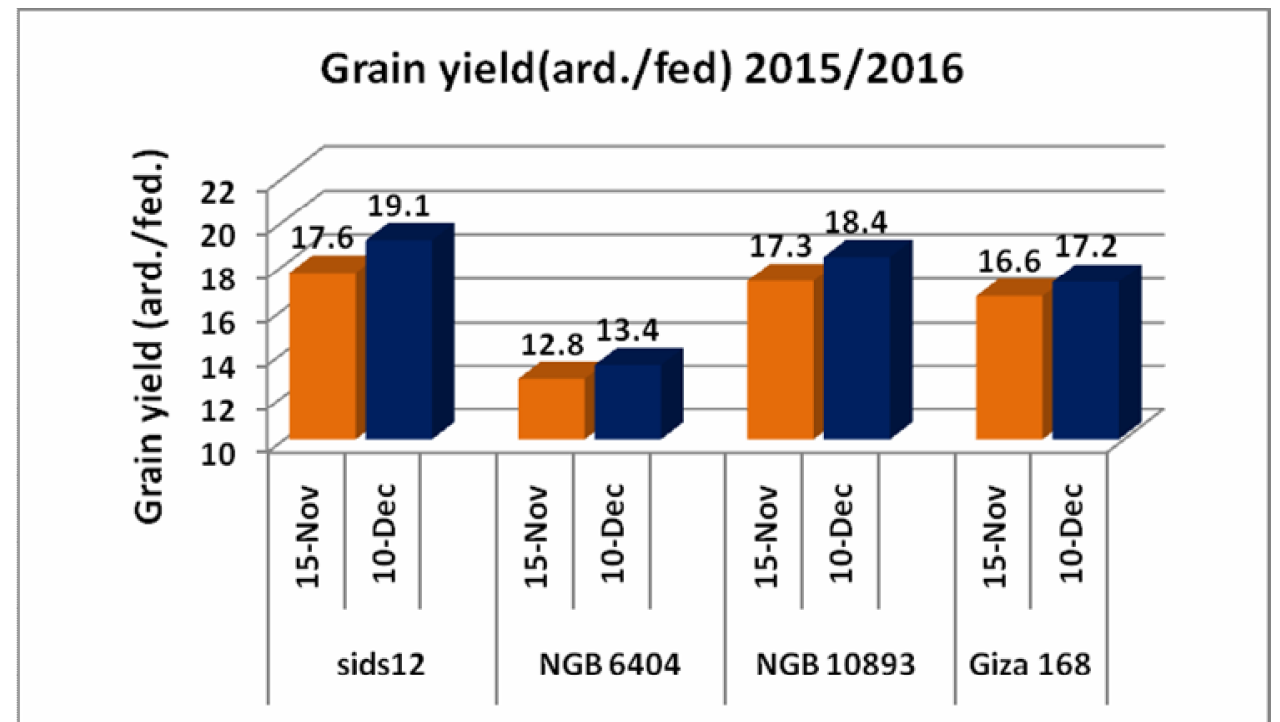

Figure (1): Grain yield (ard./fed.) for some bread wheat genotypes under two planting dates in 2015/2016.

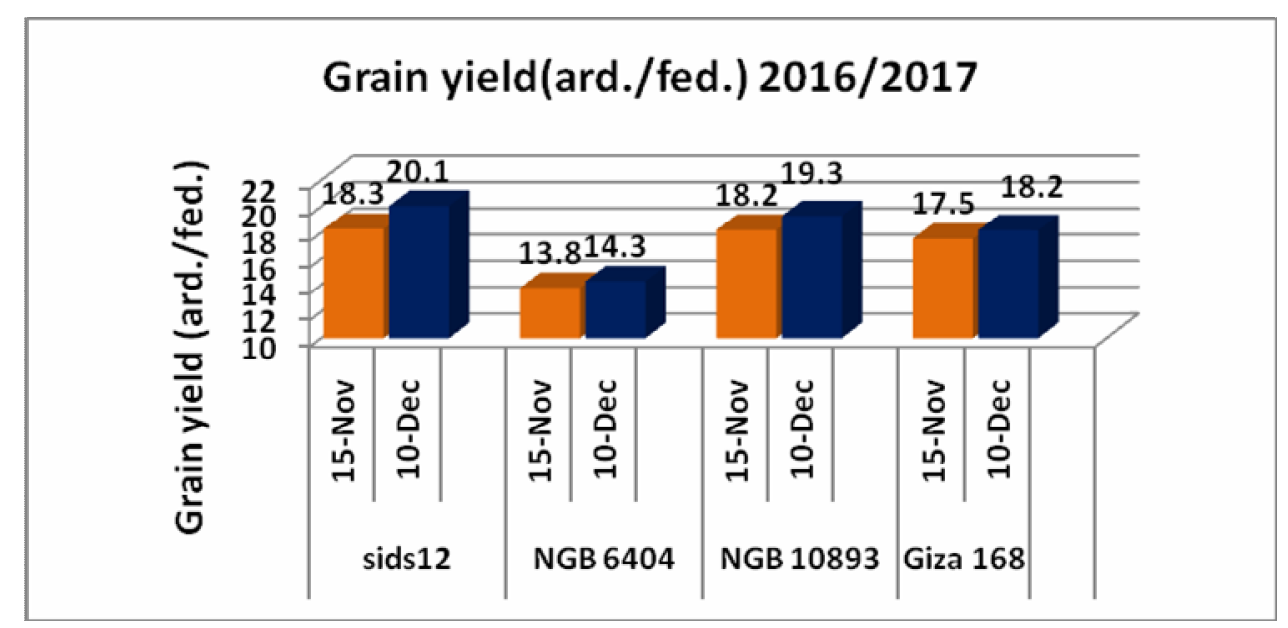

Figure (2): Grain yield (ardab/fed) for some bread wheat genotypesunder two planting dates in 2016/2017. 


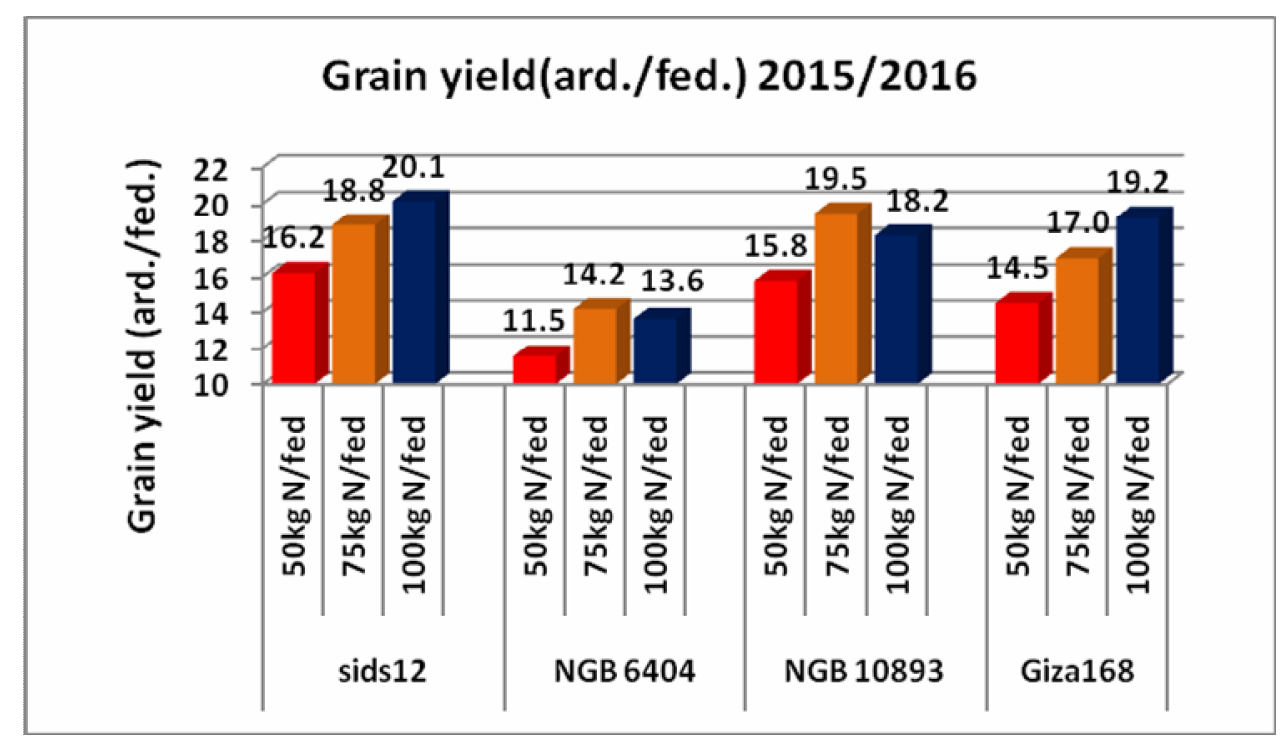

Figure (3): Grain yield (ard./fed.) for some bread wheat genotypes under three nitrogen fertilizer levels in 2015/2016.

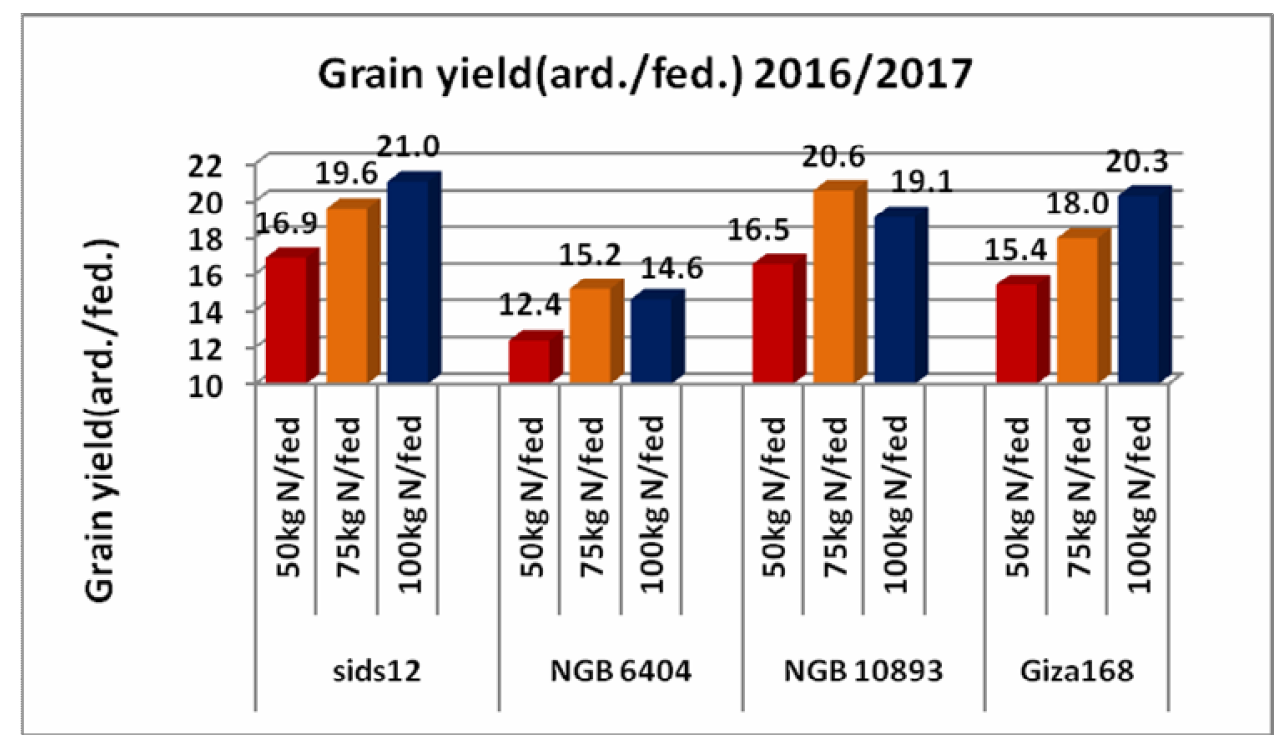

Figure (4): Grain yield (ard./fed.) for some bread wheat genotypes under three nitrogen fertilizer levels in 2016/2017. 


\section{References}

Abd El-Kreem, Thanaa H. A. and E.G.G. Ahmed (2013). Evaluation of new bread wheat (Triticumaestivum L.) cultivars in sandy soils under different irrigation regimes and nitrogen fertilizer rates for yield and its components. Alex. J. Agric. Res.. 58 (3):241-250.

Abdel nour, Nadya A.R.and H.S.A. Fateh (2011). Influence of sowing date and nitrogen fertilization on yield and its components in some bread wheat genotypes. Egypt. J. Agric. Res., 89 (4):1413-1433.

Ahmed, G.A.; M.M. Tawfik ; and M.S Hassanein (2011). Foliar Feeding of Potassium and Urea for Maximizing Wheat productivity in sandy soil. Australian J. Basic Applied Sci., 5(5): 1197-1203.

Ali,A.; A. Ahmad;W.H. Syed; T. Khaliq; M. Asif; M. Aziz and M. Mubeen (2011). Effects of nitrogen on growth and yield components of wheat. (Report). Sci. Int. (Lahore) 23(4): 331-332.

Ali, Amal G.M.; M.A. Omar; A.I. Nawar and S.Sh. El-Tabbakh(2016). Effect of sowing date and nitrogen fertilization level on growth and productivity of some durum and bread wheat varieties. Alexandria Sci. Exchange J. 37(4):541-549.

Allam, A.Y. (2003). Response of three wheat cultivars to split application of nitrogen fertilization rates in Sandy soil. Assiut J. Agric. Sci. 34 (1): 1-14.

Alves, M.J.F.; W.W.R. Teixeira; E. Daros; L.C. Cassol; J.A.L. Pascoalino and M.F. de Moraes (2015). Productive performance of wheat based on nitrogen fertilization in coverage. Am. J. Plant Sci. 6: 1587-1593.

Anwar, Sh.;W. Ali;Kh. Imanullah; M. Islam; S. Bashir; M. Shafi and J. Bakht (2015). Effect of sowing dates and seed rates on the agrophysiological traits of wheat. J. Envir. and Earth Sci. 5(1):135-140.
Co-Stat Statistical Software (2004). CoStat Manual Revision, 4 (2) 271.

Dagash, Y.M.I; I.M.M. Sayed Ahmed and N.A. Khalil (2014). Effect of nitrogen fertilization, sowing methods and sowing dates on yield and yield attributes of wheat (Triticumaestivum, L.). Universal J. Plant Sci. 2(6): 108-113.

Ejaz, A.W; R. Ahmad; A. Ali and S. Uliah (2007). Irrigation and nitrogen effects on grain development and yield in wheat (Triticumaestivum L.). Pak. J. Bot., 39(5): 16631972.

El-Borhamy, H.S. and A.M. Gadallah (2009). Performance and genetice parameters for some wheat genotypes under different nitrogen fertilizer levels in new reclaimed land. Alex. J. Agric. Res. 54 (3)716.

El-Gizawy, N.Kh.B. (2009). Effect of planting date and fertilizer application on yield of wheat under no. till system. World J. of Agri. Sci. 5(6): 777-783.

Enayat, A.; Sh. Lack and A. Modhej (2013). Effect of different nitrogen rates on grain yield and grain growth of bread and durum wheat genotypes. Int. J. Agron. \& Plant Prod. 4 (11): 3076-3082.

Eslami, H.;H. N. Navae; A.R. Alazmani and A.N.Shojaei (2014). Effect of sowing dates and seeding density on yield of wheat (Triticumaestivum, L.). Int. Res. J. App. \& Basic Sci. 8 (7): 836-838.

Faizy,S.E.D.; S.A. Mashali; S.M. Youssef and Shaimaa M. Elmahdy (2017). Study of wheat response to nitrogen fertilization, micronutrients and their effects on some soil available macronutrients. J. Sus. Agric. Sci. 43(1): 55-64.

Gheith, E.M.S.; Ola Z. El-Badry and S.A. Wahid (2013). Sowing dates and nitrogen fertilizer levels effect on grain yield and its components of different wheat genotypes. Re- 
search J. of Agri. and Biol. Sci., 9 (5): 176-181.

Gomez, K.A. and A.A. Gomez (1984). Statistical Procedures for Agricultural Research. ${ }^{\text {nd }}$ Ed, John Wiley and Sons, Ins. New York, U.S.A.

Gul, H.; B. Saeed; A.Z. Khan; U. Latif; Kh. Ali; J. ur-Rehman and M. Saad-ur-Rehman (2012). Yield and yield contributing traits of wheat cultivars in relation with planting dates and nitrogen fertilization. ARPN J. Agric. \& Biol. Sci. 7(6): 386-391.

Kiss, T.; K. Balla; J. Bányai, O. Veisz and I. Karsai (2013). Effect of different sowing times on the plant developmental parameters of wheat (Triticumaestivum, L.). Cereal Res. Commun.1-13.

Lak, M.; A. Farnia and M. Shaban (2013). Effect of different sowing dates on yield components of wheat (Triticumaestivum, L.) cultivars in LorestanProvience. Iran. Adv. Agric. Biol.1 (4): 89-93.

Malik, A.U.; M.A. Alias; H.A. Bukhsh and I. Hussain (2009). Effect of seed rates sown on different dates on wheat under agro-ecological conditions of Dera Ghazi Khan. J. Animal \&Plant Sci.19(3): 126-129.

Munsif, F.; M. Arif ; M.T. Jan ;K. Ali and M.J. Khan (2015). Influence of sowing dates on phenological development and yield of dual purpose wheat cultivars. Pak. J. Bot. 47(1): 83-88.

Protic, R.; M. Mladen; P. Nada; J. Zivota and J. Predrag (2007). The test weight of several winter wheat genotypes under various sowing dates and nitrogen fertilizer rates. Romanian Agric. Res., 43-46.

Rahman, M.M.; A. Hossain; M.A. Hakim; M.R. Kabir and M.M.R. Shah (2009). Performance of wheat genotypes under optimum and sowing condition. Int. J. Sustain. Crop Prod., 4(6): 34-39.

Sadek, I.M.M. (2000). Evaluation of some new wheat genotypes under different irrigation intervals and $\mathrm{N}$ fertilization levels in sandy soils. J. Agric. Sci. Mansoura Univ. 25 (12): 7485-7499.

Said, A.; H. Gul; B. Saeed; B. Haleema; N.L. Badshah and L. Parveen (2012). Response of wheat to different planting dates and seed rates for yield and yield components. Arpn. J. of Agric. and Biol. Sci. 7 (2):138-140.

Sebastiano, D.; R.Tognetti ; E. Desiderio and A. Alvino (2005). Effect of foliar application of $\mathrm{N}$ and humic acids on growth and yield of durum wheat. Agronomy for Sustainable Development, Springer Verlag (Germany), 25 (2): 183-191.

Shajaripour, Sh. and M. Mojaddam (2014). The effect of split application of nitrogen fertilizer and nitrogen level on the yield and yield components of barley. Ind. J. of Fundamental and App. Life Sci.: 2231- 6345 .

Sun, H., L. Shao; S. Chen; Y. Wang and X. Zhang (2013). Effects of sowing time and rate on crop growth and radiation use efficiency of winter wheat in the North China Plain. Int. J. Plant Prod.7(1):77-82.

Tahir, M.; A. Ali; M. A. Nadeem; A. Hussain and F. Khalid (2009). Effect of different sowing dates on growth and yield of wheat (Triticumaestivum, L.) varieties in District Jhang. Pak. J. Life Soc. Sci. 7(1):66-69.

Upadhyay, R. G.; R. Ranjan and P. S. Negi (2015). Influence of sowing dates and varieties on productivity of wheat under mid-Himalayan region. Uttarakhand 33(2): 19051909.

Youssef, S.M.; S.E.D. Faizy; S.A. Mashali; H.R. ElRamady and Sh. Ragab (2013). Effect of different levels of NPK on wheat crop in North Delta.Annual Conference of German Soil Science Society. 7-12 Rostock, Germany. 
سلوك بعض التر اكيب الور اثية من قمح الخبز تحت مواعيد زراعة ومعدلات سماد نيتروجينى مختلفة في محافظة سورهاج

ياسر أحمد محمد حفني، نحيف ابر اهيم محمد

قسم المحاصيل ـ كلبة الزر اعة - جامعة سو هاج

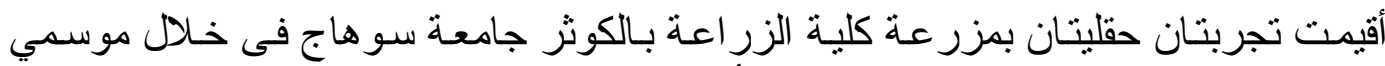

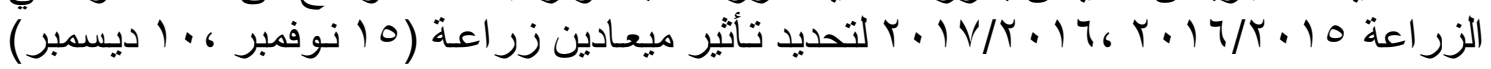

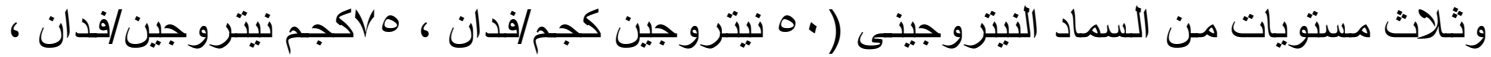

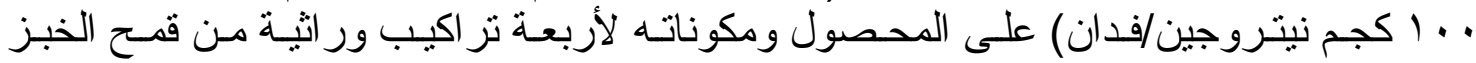

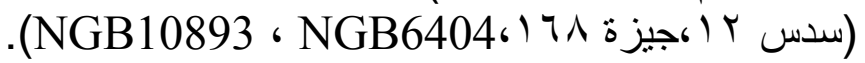

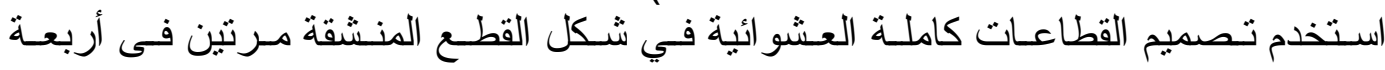

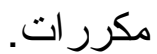

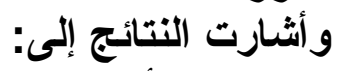

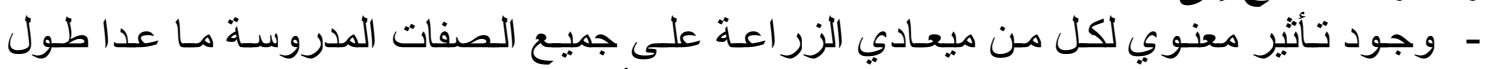

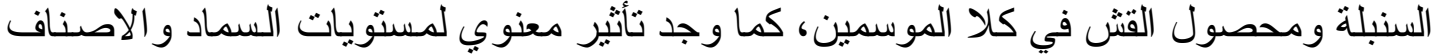

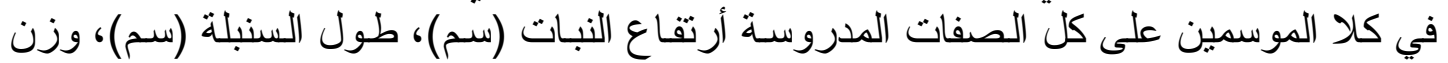

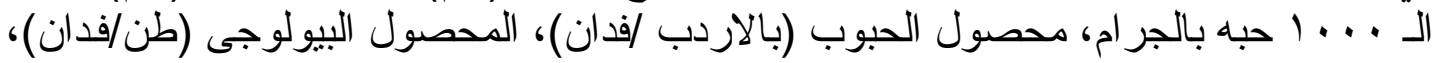

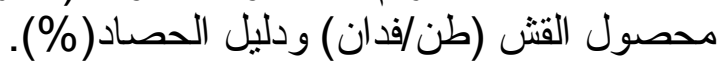

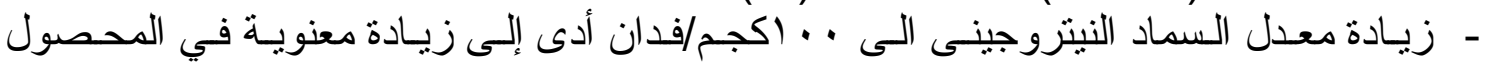

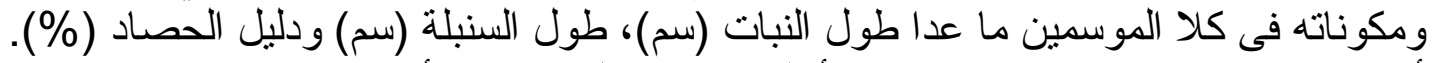

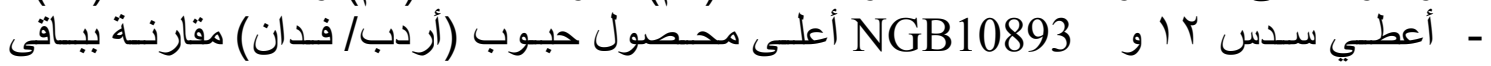
التز اكيب الور اثثية في كلا الموسمين.

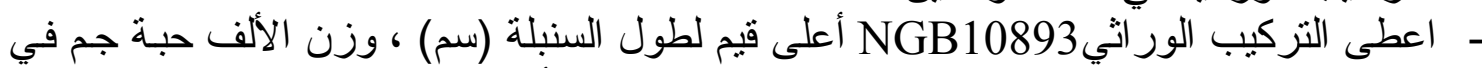

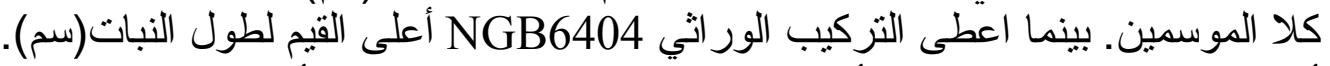

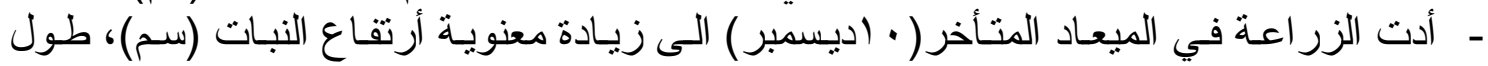

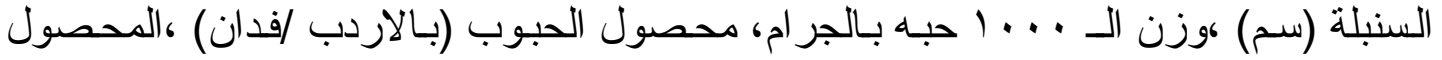

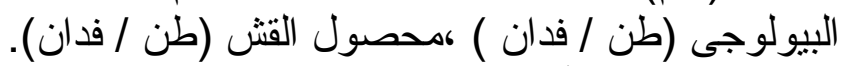

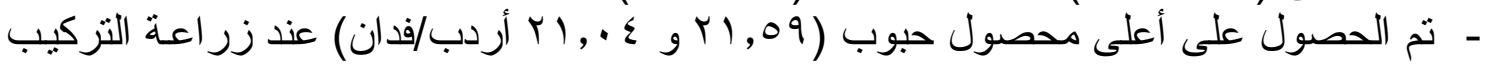

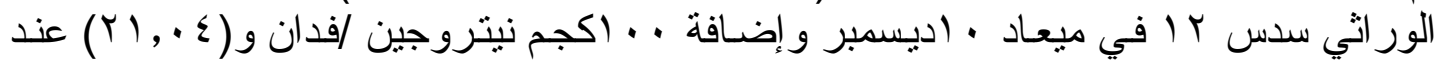

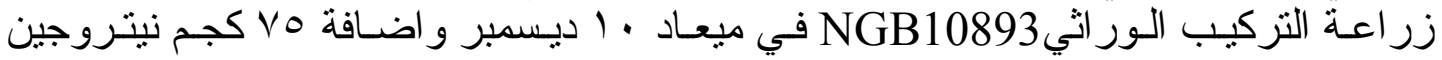
للفدان علي التزتيب. 